\title{
Analysis on Industrial Structure and Competitive Strategies in Liner Shipping Industry
}

\author{
Ziyi Gao ${ }^{1} \&$ Shigeru Yoshida ${ }^{1}$ \\ ${ }^{1}$ Department of Maritime Logistics, Kobe University, Kobe, Japan \\ Correspondence: Ziyi Gao, Department of Maritime Logistics, Kobe University, Higashinada, 658-0022, Kobe, \\ Japan. E-mail: jessicagao@hotmail.com
}

Received: August 5, 2013

doi:10.5430/jms.v4n4p12
Accepted: September 7, 2013

Online Published: November 8, 2013

URL: http://dx.doi.org/10.5430/jms.v4n4p12

\begin{abstract}
The demand for maritime transport is derived primarily from the needs of industrial processes. Therefore, the boom and bust in the shipping market are typically motivated by the global economic situation. Under such an unpredictable and uncertain circumstance, for striving for a competitive position in market, explicit strategies are very significant to liner shipping companies. This paper investigates trends in liner shipping industry and analyzes the industrial structure by five forces analysis. By means of five forces analysis, competitive rivalry and barging power of buyers show a relatively strong force in liner shipping industry. At last, seven competitive strategies are proposed for liner shipping companies by taking into account of critical forces and trend in liner shipping industry.
\end{abstract}

Keywords: competitive strategies, five forces analysis, liner shipping companies

\section{Introduction}

International trade proliferation depends to a very large extent on the efficient movement of cargoes from production sources to points of consumption. The liner shipping companies as carriers of cargoes transport representing approximately one-third of the total value of global trade. Liner shipping companies play a prominent role in facilitating international trade, not just by enabling the physical transport of the cargoes but also through their involvement in the commercial and marketing aspects of global trade (Panayides and Wiedmer, 2011). The demand for maritime transport is derived primarily from the needs of industrial processes; therefore the boom and bust in the shipping market are typically motivated by the industrial cycles and global economic situation.

As shown in Figure 1, economic activity, as measured by the global Gross Domestic Product (GDP), increased by an average 4.1 percent per year in 2000-2008, while world trade increased by 6.1 percent annum during 2000-2008. Worldwide container shipping volumes grew at an average annual growth rate of $9.6 \%$ in the same period, which closely related to the increase of the economic and trade activity. After the global financial crisis hit in 2008, in tandem with the world economy decelerated and reduced trade, the buoyant growth in shipping market ended. World GDP in 2012 rose by $3.3 \%$, down from the growth of $5.1 \%$ in 2010 . Although global container traffic continued to grow in 2012, the growth rate slipped $5.5 \%$ in 2012 from 2010.

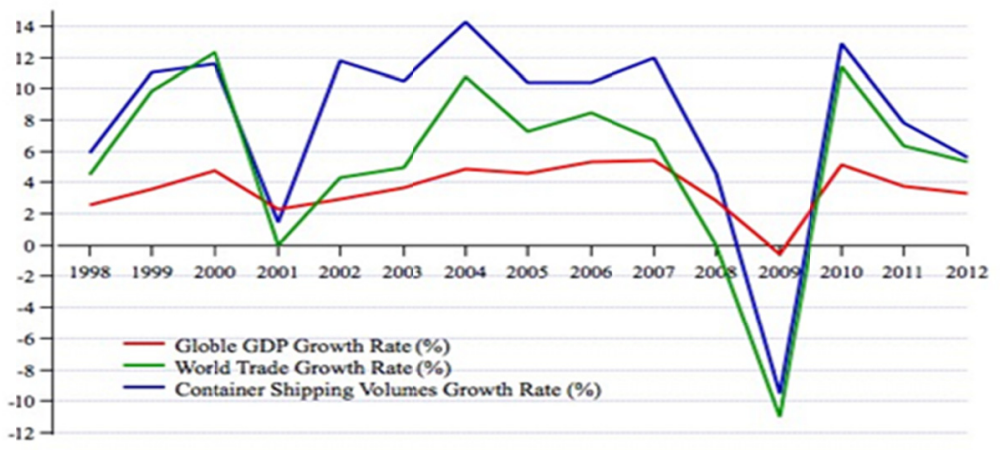

Figure 1. Trends of world economic growth, world trade growth and container shipping volumes growth Source: IMF, WTO and CLARKSON RESEACH 
Under such dire circumstances, liner shipping companies have to make clear strategies and implement them effectively so as to survive. Strategy is concerned with how businesses achieve competitive advantage (Slater and Olson, 2000). And it is a set of decision making rules or procedures for guidance of organizational behaviour. According to strategy, managers mean large scale action, future oriented plans for interacting with the competitive environment to achieve long-term objectives of organization. Therefore Kinsella defined strategy as "the plans and activities developed by an organization in pursuit of its goals and objectives, particularly in regard to positioning itself to meet external environmental demands relative to its competition" (Kinsella, 2002). Strategy is important in shipping because it facilitates the identification of business opportunities, gives an objective view to solve business problems, provides a framework to improve internal and external collaboration, assists in controlling business activities, minimizes negative effects when threats arise, helps make better decisions, guides effective allocation of resources, provides methods to manage changes, and nurtures consistency in the management of the shipping business. In recent year, the strategy of liner shipping industry has become a popular subject of study for both industry practitioners and researches. Cariou (2008) offeres an overview of the three main strategies in the liner shipping market during the last 15 years: horizontal integration, vertical integration and the investment in bigger vessels. It tries to explain why these strategies took place and are closely interrelated. Lorange (2009) draws on his extensive experience in the shipping industry to show how companies can adapt to the fast-moving and volatile world of maritime business by devising strategies for future success, including specialization and innovation. Brooks (2000) introduces a framework for understanding the choice of structural options, e.g., alliances, mergers, acquisition or joint ventures, within the context of decisions about strategy. In the existing literature, most studies investigate strategies based on reviewing literature, and pay more attention on strategies for industry in a broad sense. However, this study focuses on specific strategies for liner shipping companies. In the past several decades, liner shipping industry is in a constantly evolving environment. Some new changes and trends have been evident, particularly the changes of industrial structure. The aim of this study is to propose appropriate competitive strategies for liner shipping companies by analyzing the industrial structure.

\section{Trends in Liner Shipping Industry}

The growing international competitive pressure, combined with high capital intensity and traditionally strong dependencies on volatility of the global economic condition, has resulted in an intensified impact on margins and continuously rising financial risks for the maritime industry in recent years (Notteboom, 2004). Over the past several decades, liner shipping market is in a constant state of flux with economic development. Four main trends in liner shipping industry are discussed in this section. They are bigger container ships, strategic alliance, mergers and acquisitions of global carriers and e-commerce.

\subsection{Bigger Container Ships}

The use of containers started during the Second World War, and the first ship of 610 teus specifically designed for container transportation appeared in 1960, since 1980, the container ship is developing fast. The first container ship of around 4500teus was built in 1984, thereafter, the largest size for a container ship remained at this level for almost a decade (Cullinane and M. Khanna, 1992). The ships are growing both in number and the size of container vessels. The world container fleet consists of some 5,087 ships (August 2012) with a combined capacity of 16 million teus, the capacity has been increased by about $400 \%$ over the last fifteen years.

One of the key factors contributing to this trend is the introduction of the so-called post-Panamax container ships. Panamax vessel is a ship that was constructed with the maximum dimensions to safety pass through the Panama Canal. The first post-Panamax container ships were introduced in 1988. Such a ship has a maximum beam of $32.3 \mathrm{~m}$, which exceeds the width limit of the Panama Canal. By 1996 the capacities of post-Panamax container ships reached to 6,600teus. Several years later, Super-post-Panamax container ships -- vessels with capacities of at least 8,000 20 -foot equivalent units were built and such a vessel became the backbone of the operating fleet of the top global liner shipping companies. Orders for 8,000-TEU-plus ships peaked in 2007 at 181 vessels of 2 million teus. Although such mega vessels present some limitations, such as larger volume of carbon air emissions and higher requirement for capacity and productivity of ports, in recent years, the tendency of bigger container ship has not changed. The largest container ships delivered today have a capacity of about 16,020 teus. Table 1 shows the generations of container ship. 
Table 1. Container ship generations

\begin{tabular}{lll}
\cline { 2 - 3 } Year & Type & Capacity (TEU) \\
\cline { 2 - 3 } $1960-1970$ & Converted cargo vessel/tanker & $500-800$ \\
\hline $1970-1980$ & Cellular containership & $1000-2500$ \\
\hline $1980-1988$ & Panamax Class & $3000-4000$ \\
\hline $1988-2000$ & Post Panamax & $4000-6800$ \\
\hline $2000-2002$ & Super Post Panamax & $800-8000$ \\
\hline $2003-2006$ & New Panamax & $11000-14500$ \\
\hline $2006-$ & Ultra Large Container Vessel & $14500-16020$ \\
\hline
\end{tabular}

\subsection{Strategic Alliance}

The formation of global strategic alliances in the liner shipping industry dates back to the end of 1995. Hung (1992) defined strategic alliances as long-term cooperative business agreements between two or more companies to pool, exchange and/or integrate specific company resources for achieving some agreed objectives. Strategic alliances in liner shipping aim at cooperation in the employment and utilization of ships over particular routes including type/size of ship, sailing schedules and itineraries, use of joint terminals and container co-ordination on a global scale (Panayides and Wiedmer, 2011).

Liner shipping companies operate in an extremely volatile and uncertain environment. Fuel prices were soaring despite the world economic depression, adding greatly to the shippers' operating costs, but the freight rate has remained stagnant, which leads to the decrease of profit margin in major markets. Therefore many liner shipping companies turned toward strategic alliance from former competitive behavior-price war, which favors cost minimization, economies of scale attainment, market and service network integration, risk sharing and reducing the pressure of competition.

As in Figure 2, container carriers operating in global market can be grouped in to five main strategic alliances: (1) Grand alliance: Hapag Lloyd, OOCL and NYK, which occupied 9.1\% of market share in the liner industry. (2) New world alliance: APL, Hyundai M.M and MOL owned 8.6\% of the global slots (3) CKYH alliance: COSCO, K-Line, Yang Ming and Hanjin, Shared $12.1 \%$ of global capacities. (4) Maersk sealand ranked as the number one with $15.3 \%$ of market share (5) Evergreen Marine Company also owned 4.2\% of market share.

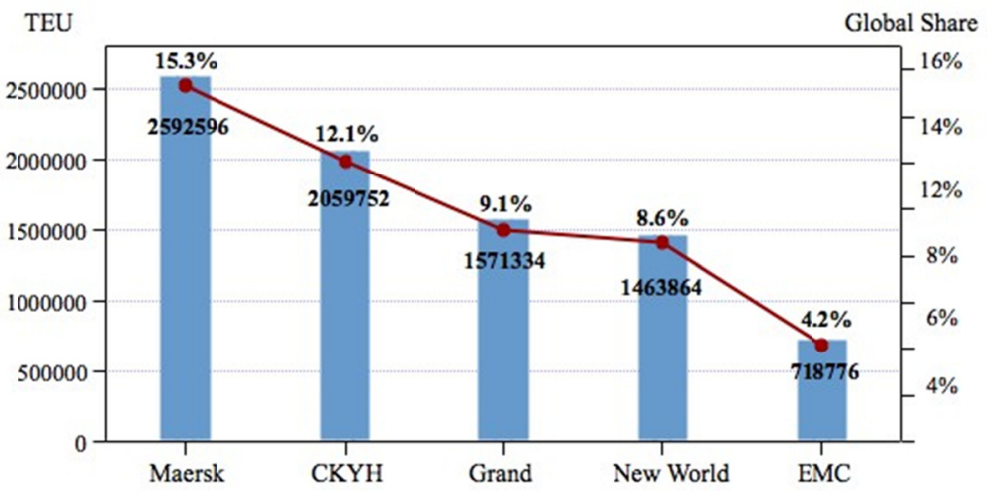

Figure 2. Capacities and shares of five main alliances

Source: ALPHALINER (MAR.2013)

Furthermore, by March 2012 the G6 Alliance formed following leading container shipping owners: New World Alliance members - APL, Hyundai Merchant Marine, and Mitsui O.S.K Lines and Grand Alliance members Hapag-Lloyd, N Y K and OOCL, which create one of the largest vessel networks in the Asia-to-Europe trade lane.

\subsection{Mergers and Acquisitions of Global Carriers}

Due to the growing international competitive pressure and high capital intensity, the shipping industry has experienced significant growth in merger and acquisition activity in recent years. In general, firms seek mergers and 
acquisitions to capture economies of scale in production, increase management efficiencies and exploit synergies between rival operations and markets (Fusillo 2009). Some global carriers have responded to challenges in liner shipping market by traditional conferences or alliances, bigger container ships. Since the Ocean Shipping Reform Act of 1998 weakened the traditional conference system in US markets that to preserve competitiveness, for reducing costs and keeping market share, major carriers sought membership in global alliances. Moreover, containership technology has produced enormous ships that contribute to economies of scale, and hence reduce unit costs, but they demand huge investments and expenditures, such as fixed costs, fuel costs and administrative expenses. Meanwhile excess capacity in times of recession and irregular runs of cash flows exist. Various carriers are forced to enhance their competitive position by mergers \& acquisitions.

Recent mergers, take-overs and shareholding agreements include the acquisition of Norasia Line by CSAV in 2000, the purchase of Farrell Line and Harrison Line and P\&O Nedlloyd by Maersk Line in 2000 and 2005, the acquisition of Delmas in 2006, U.S Line, Comanav and Cheng Lie Navigation in 2007 by CMA-CGM.the purchase of Kieng Hung, Columus Line and Costa Container lines by Hamburg Lines in 2003, 2004 and 2008, respectively.

Figure 3 shows market share of top 20 in liner shipping industry. The top 20 carriers controlled a combined carrying capacity of 13 million TEUs in 2012, which increased from 52\% of the global container total capacity in 2000 to $83.7 \%$ in 2012, according to Alphaliner. Maersk Line, the world's largest container carrier and the market leader, increased its market share from $12 \%$ in 2000 to 15.3 in 2012, MSC, the second largest carrier owned $13.6 \%$ of market share, and CMA CGM, the third carrier occupied 8.4\% of market share in 2012 (see Figure 3).

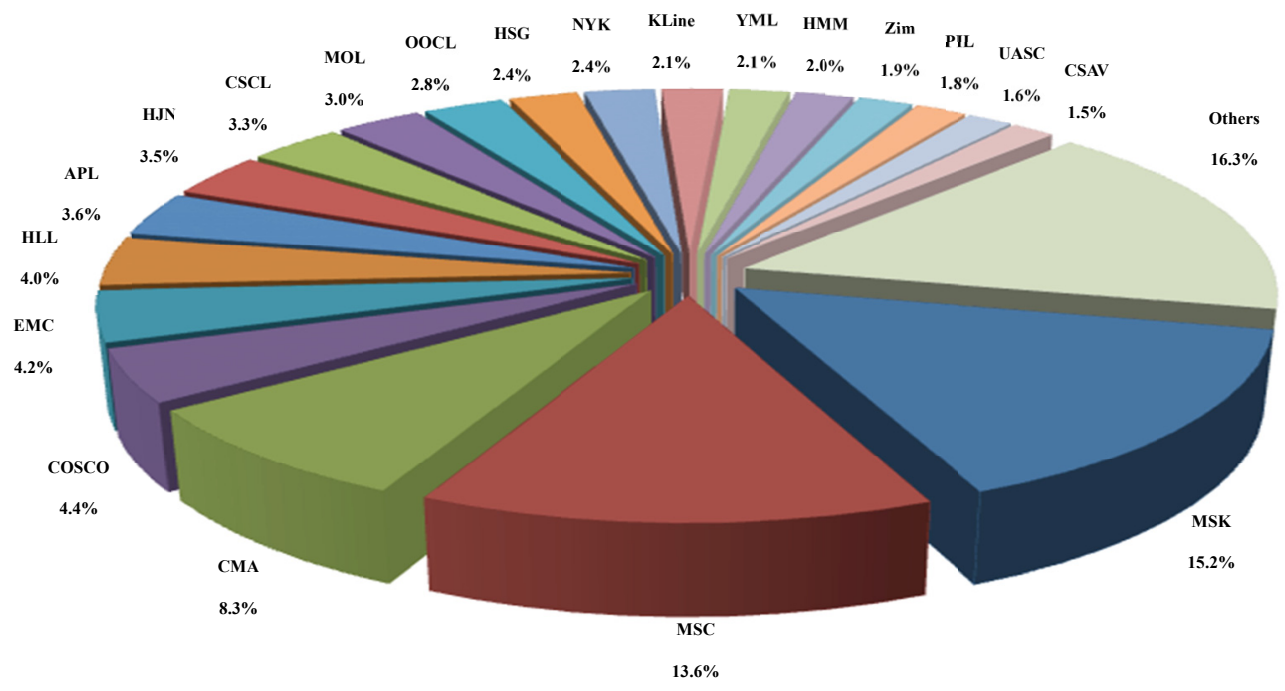

Figure 3. The market share of the top 20 carriers

Source: ALPHALINER (MAR.2013)

\subsection{E-commerce}

International shipping is a quite complicated service business because of its customers, partners and collaborators, which are scattered all over the world. Under rapid changing business environments with increased flexible distribution operations, tighter inventory control and faster, more efficient processing, information technologies are becoming increasingly important in shipping industry. It has also become a key to gain market competitive advantage over rivals.

For customers, it is the norm to go online to perform day-to-day activities such as booking, shipping instructions, remote printing of bills of lading and cargo tracking, which bring more convenience. For shippers and carriers, carrying out these functions online increases efficiencies, expands automation and reduces operating cost. Gradually, e-commerce has moved into the mainstream of carriers-to-customers business. Some carriers now depend on e-commerce for more than 50 percent of their total container volume. Others see smaller percentages but have rapid growth. Shippers that were early adopters now rely on e-commerce to process as much as $95 \%$ of their total ocean container volume (post \& parcel).

\section{Analysis of Industrial Structure}

The economic structure of an industry is not an accident. Its complexities are the result of long-term social trends and economic forces (Linton, 2005). Industrial structure determines the competitive rules and strategies. Analysis liner 
shipping industrial structure will provide essential insight for strategy. Porter's five forces analysis is an industry analysis model created by Michael E. Porter in 1979 as a tool for developing corporate strategies to become or remain competitive in an industry. It helps a company exploit opportunities and overcome threats in the external environment of the business (Porter, 1980). According to porter, there are five forces that affect the competitive environment of an industry as illustrated in Figure 4. The five forces include rivalry among competitors, threat of new players, bargaining power of suppliers, bargaining power of buys, and the threat of substitute products.

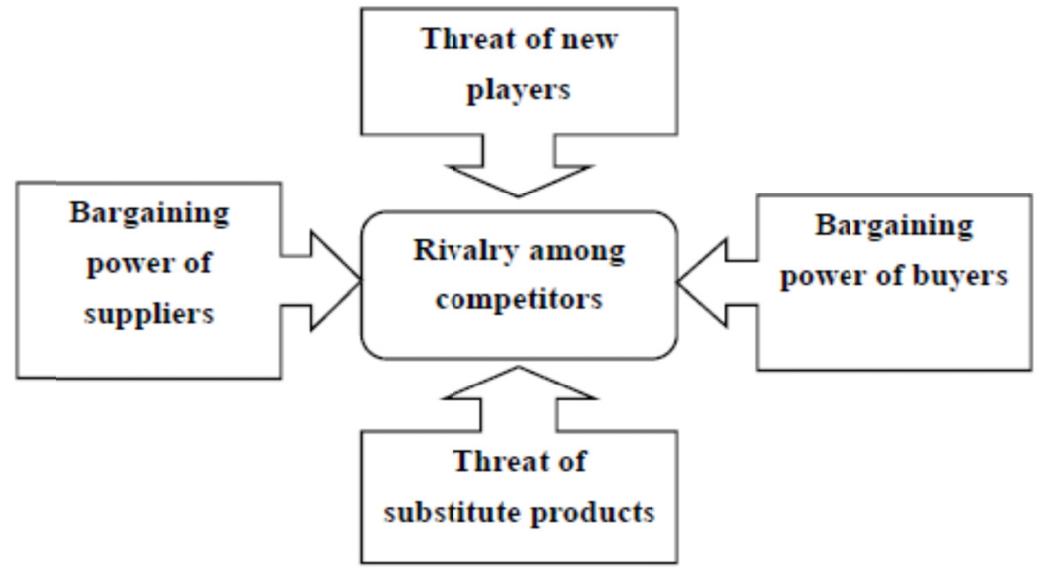

Figure 4. Diagram of Porter's five forces

Source: Porter 1980

\subsection{Bargaining Power of Suppliers}

The bargaining power of a supplier is high when there are a limited number of dominant suppliers that can dictate the price for their products and services. Conversely, suppliers will have a weak bargaining power when there are many competent suppliers servicing an industry. According to Porter, suppliers become powerful in the following situations: (ClilT, 1990)

1) The input is important to the buyer.

2) The supplier industry is dominated by a few large suppliers who have secured market positions and are not easily affected by competitive market conditions.

3) The products of the suppliers are unique to an extent that it will be difficult or costly for the buyers to switch from one supplier to the other.

The major suppliers to the liner shipping industry include oil producers, shipbuilders, and port terminals.

The increase in crude oil prices over the recent year has led to a sharp hike in bunker fuel. Singapore's bunker price has doubled from 2005 to 2012 (See Figure 5). A high and unstable bunker price has given liner shipping companies a relatively worse bargaining position.

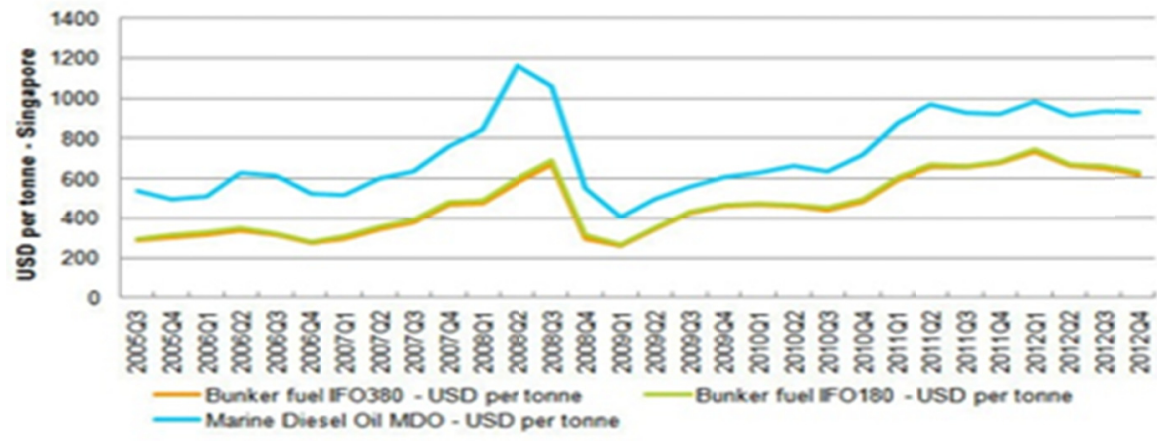

Figure 5. Marine bunker fuel spot prices used per tone

(Average unit value, FOB-Singapore)

Source: Bunker world 
As a result of the economic crisis, global shipbuilding industry has been going through a downturn for the last four years. Global commercial ship orders were down $48 \%$ year on year in the first nine months of 2012 and order backlog fell to half of the level in first half of 2008.In addition, traditional shipyards in Europe, Japan and Korea being changed by the emerging shipyards in China change. In the fierce competition and gloomy market environment, shipbuilders do not have much bargaining power.

The bargaining power of port terminal is determined primarily by advantages over the other competitors, such as unique geographic location, port facilities or service quality. Like Singapore and Colombo port are superiorly located to act as hub point for Southeast Asia and Indian subcontinent respectively. Good facilities and infrastructure and high service quality of port can bring better bargaining power.

\subsection{Bargaining Power of Buyers}

Just as suppliers wish to maximize profits, buyers wish to minimize the price they pay. Bargaining power of buyers refer to the potential of buyers to bargain down the prices charged by the firms in the industry or to increase the firms cost in the industry by demanding better quality and service of product.

Powerful buyers can extract profits out of an industry and even cause a price war amongst the companies in the industry. They improve their bargaining power by purchase in large quantities; they seek better service and quality assurance under the conditions of the same price by negotiation.

Generally, several factors determine bargaining power of buyers.

1) Number of customers- if there are a few buyers with significant market share.

2) Their size of their orders- if it is large volume.

3) Number of firms supplying the product- if there are many alternative suppliers.

4)The cost of switching- How much does it cost for customers to switch, the higher their switching costs the less power they have to move.

While apart from above mentioned factors, supply and demand of capacity strongly affects bargaining power of buyers in liner shipping industry. As shown in Figure 6, Ratio between demand and supply is decreasing gradually over past 15years. Market is in the condition of oversupply in some major routes. According to the analysts at Alphaliner, carriers will bring on-line a record level of new capacity in 2013. The container fleets of the 21 largest carriers Alphaliner follows are expected to grow by $9.0 \%$ in 2013 (net of potential scrapping). That represents some 1.75 million teus worth of new vessel capacity to be delivered this year, after adjusting for some slippage of expected 2012 deliveries into 2013.If accurate, those new ships would exceed the 1.57 million teus that was delivered in 2008, making 2013 the highest level of added capacity ever recorded.[15]

A consequence of this oversupply is the impact on shipping freight rates. According to Alphaliner, the overcapacity situation in the container shipping industry resulted in a collapse of charter rates and relatively low and highly variable freight rates. Oversupply and low freight rates increase bargaining power of buyers in liner shipping industry.

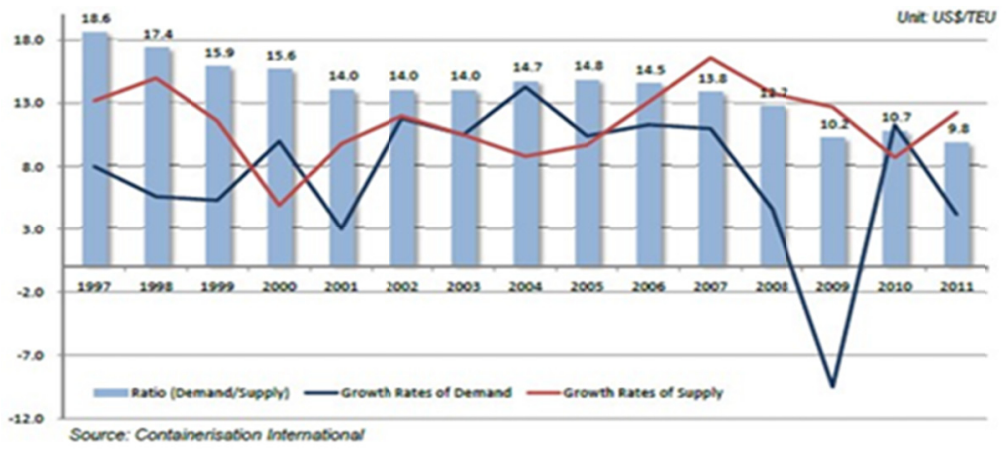

Figure 6. Supply demand of liner shipping market

Source: Containerization International

\subsection{Threat of New Players}

Entry of new players has the effect of increasing the competition for market share and lowers the current costs in that market. If an industry is highly attractive with high levels of profits, easy entry and exit, it will attract new entrants who can aggravate the competition and drive down profitability. 
The following are the factors which define the level of barriers of entry.

1) Investment cost-How much wills it cost to enter the market.

2) Economies of scale- unit costs determine difficulty of newcomers to break into the market and compete effectively.

3) Government Regulation-if regulation is a barrier to entry.

4) Access to suppliers and distribution channels-if there are accesses and distribution channels for new player to enter the market.

Liner shipping industry depends heavily on a complex chain of logistical support. Huge amount of capital investment is required hardware and software. For example, a 4000 teus vessel costs around USD60 million, a fleet of 7 vessels to run a fixed day weekly service means a requirement of about USD420 million capital investments. In addition, building up information system, staff employment and training also have high requirement for capital investment. The high level of sunk costs may prevent new players to enter.

In many less developed countries, shipping industry is managed by government which has a large involvement in capital investment and administrative controls. Various protectionist policies form a barrier to new players.

Distribution channels in liner shipping industry are difficult to open up because of fragmented customers in the market and the particularity of shipping service. Experienced employees especially of professional sales team are important to new players, but this often has to pay higher than market rate to attract talent and they are also hard to penetrate into the market within a short period of time.

Therefore, it is not easy to enter liner shipping industry for a new player. In particular, there are some restrictions on capital and government policies.

\subsection{Threat of Substitutes}

Substitute products refer to the products having ability of satisfying customers' needs effectively.

The customers may shift to the substitutes, if the substitute is more attractive in terms of price or performance. The companies have to improve the performance of their products by reducing costs and therefore prices and by differentiation when there is a threat from a rival product. The extent of the threat depends upon:

1) Importance of your product / service to the customer

2) The extent to which the price and performance of the substitute can match the industry's product

3) Customer loyalty and switching costs

Although economical air transportation system produces some effects on liner shipping industry in recent year, liner shipping as one of transportation industry still has a certain advantage. In general, Air transportation focus on a faster cargo transportation means for light weight, high value cargo, but also at a much higher freight rate than maritime transportation, even economical air transportation.

Because of different target customers, liner shipping still dominates the market of large cargo volumes transportation. Therefore, air transportation can rarely be a substitute of liner shipping.

\subsection{Competitive Rivalry}

Rivalry refers to the competitive struggle for market share and high profits between companies in an industry. It is also the most common threat that most businesses have to overcome. Porter has said that this is the driving force behind his model since companies must compete in the free market to earn profits. Several factors determine the degree of competitive rivalry, the main ones are (SCDigest):

1) Number of competitors in the market- Competitive rivalry will be higher in an industry with many current and potential competitors

2) Market size and growth prospects- Competition is always most intense in stagnating markets

3) Product differentiation and brand loyalty- The greater the customer loyalty the less intense the competition. The lower the degree of product differentiation the greater the intensity of price competition

4) Exit barriers- If it is difficult or expensive to exit an industry, firms will remain thus adding to the intensity of competition 
As services provided by the carriers in the market are similar, for customers, the switching cost is not high which has intensified the competition in the market. The carriers have to wage a price war to retain its customers and to maintain its market share.

Liner shipping companies have a high upfront investment in fleets, technical equipments and intangible assets. In recent years, with market demand and an improved technology, bigger ships have become main stream in market. Hence, the resale value of old and small ships has dropped tremendously.

Therefore, the products liner shipping companies provide is little lower the degree of differentiation and high barriers to exit because of high sunk costs, which leads to fierce price competition, especially when market is stagnant.

On basis of above five forces analysis of industrial structure, competitive rivalry and barging power of buyers show a relatively strong force in liner shipping industry. For striving for a competitive position in market, liner shipping companies have to take into account of these critical forces in its strategic planning.

\section{Competitive Strategies for Liner Shipping Companies}

An explicit strategy can determine a firm's long-run competitive strength and generate a persistently higher rate of profit than its rivals by creating a sustainable competitive advantage (Riley, 2012). Porter has argued that a firm's competitive advantages over the other competitors are based on one of two headings: cost advantage and differentiation. By applying these advantages in either a narrow or a broad scope of buyers, three generic strategies result: Cost Leadership Strategy, Differentiation strategy and Focus strategy (Porter, 1980):

"Cost Leadership offers the lowest costs products to the entire market. Differentiated offers highly unique products (as perceived by the customer) to the entire market, and Focus offers products which serve the needs of a niche segment of the market."

In this study, seven strategies are selected by analysis on trends and industrial structure in liner shipping industry (see Table 2). Due to the generic nature of liner shipping, the service offered by liner shipping companies are similar, and gives little rooms to differentiate its product in the market. In addition, because of high upfront investment, fierce competition and high bunker price in recent, lowering cost of operations is becoming very important for liner shipping companies. Cost leadership has become one of the common goals set in liner shipping industry. The intended strategy scheme is based on a world-wide liner shipping company perspective and particularly integrates the cost leadership strategy as the domain of company's vision.

Table 2. Strategies for liner shipping companies

\begin{tabular}{ll}
\hline Strategy \\
\hline 1. & Profitable growth \\
2. & Reduction of costs \\
3. & Increased customer satisfaction \\
4. & Improved (extending) service coverage (delivery service) \\
5. & Improving convenience \& IT based interfaces \\
6. & Improved internal business processes \\
7. & Increased satisfaction of employees \\
\hline
\end{tabular}

First and foremost, due to lower freight caused by over-supply and intense competition in the globalised liner shipping market, liner shipping companies still are currently characterized by low profit margin despite the economy's modest recovery. The level of capacity utilization depends on the growth of cargo, the speed with which existing operators introduce new and larger vessels into liner shipping service, even exits of operators from the market. Therefore, reduction of costs and profitable growth to survive that is prior to all others for all of liner shipping companies.

Besides, customer service is highly important to liner shipping industry that itself is service industry. As analyzed before, service provided by the carriers in the market is very similar, i. e. differences among carriers are small, but a better service and operating process will help to make a company more distinctive in the market. Providing cheaper, faster, more accurate and convenient services is fundamental guarantee for the invincible status. Therefore, increasing customer satisfaction by high quality services is an indispensable strategy to liner shipping companies. To make customer satisfied, more broadly service coverage and more efficient business process are very influential factors. In addition, as e-commerce has been widely used in liner shipping industry, development of IT also becomes 
more and more important. As result, increased customer satisfaction, improved (extending) service coverage (delivery service), improved internal business processes and Improving convenience \& IT based interfaces as critical strategies are suggested.

Last but not least, increased satisfaction of employees as a necessary strategy cannot be ignored. Employees' satisfaction should be paid great attention while most liner shipping companies nowadays only focus on financial aspect or business process. Since employees' enthusiasm and creativity are a fountainhead which the company grows strong. High Efficiency and innovation are conducive to customer loyalty and costs down, which is good for profits.

\section{Conclusions}

With the increase in the pressure of external threats in an unpredictable and uncertain market circumstance, liner shipping companies have to make clear strategies to survive. In recent, the trend of concentration of liner shipping market is more and more obvious. Especially, global strategic alliances and Mergers and acquisitions of global carriers exacerbated this change. Under the pressure of reducing unit cost, Container ship maximization also becomes obvious in liner shipping industry. Besides, now with the development of and technology, e-commerce is applied more and more extensively.

According to porter, there are five forces that affect the competitive environment of an industry; they include rivalry among competitors, threat of new players, bargaining power of suppliers, bargaining power of buys, and the threat of substitute products. Based on five forces analysis of industrial structure, competitive rivalry and barging power of buyers show a relatively strong force in current liner shipping industry.

For striving for a competitive position in liner shipping market, seven strategies for liner shipping companies are proposed in financial perspective as well as non-financial.

\section{References}

Brooks, M. R. (2000). Sea Change in Liner Shipping: Regulation and Managerial Decision-Making in a Global Industry. Oxford: Pergamon Press.

Cariou, P. (2008). Liner shipping strategies: an overview. Int. J. Ocean Systems Management, 1(1), .2-13. http://dx.doi.org/10.1504/IJOSM.2008.017778

ClilT, B. (1990). The Essence of Strategic Management. Prentice Hall.

Cullinane, K., \& Khanna, M. (1992). Economies of scale in large container ships. Journal of transport economics and policy, 33, Part 2, 185-208C.

Fusillo, M. (2009). Structural factors underlying mergers and acquisitions in liner shipping. Maritime Economics \& Logistics, 11, 209-226. http://dx.doi.org/10.1057/mel.2009.3

Hung, L. (1992). Strategic business alliances between Canada and the newly industrialized countries of pacific Asia. Management international review, 32.

Kinsella, A. (2002). Strategic Planning.

Linton, S. (2005). Industry Analysis: The Five Forces, purdue extension ec-722.

Lorange, P. (2009). Shipping Strategy: Innovating for Success.

Minarik, M. (2007). Cost Leadership \& Differentiation -An investigation of the fundamental trade-off between Porter's cost leadership anddifferentiation strategies, Stockholm School of Economics.

Notteboom, T. (2004). Container shipping and ports: An overview. Review of Network Eco-nomics, 3(2), 86-106.

Panayides, P., \& Wiedmer, R. (2011). Strategic alliances in container liner shipping. Research in Transportation Economics, 32.

Porter, M. E. (1980). Competitive Strategy. The Free Press.

Riley, J. (2012). Porter's Five Forces Model: analysing industry structure.

SCDigest's On-Target e-Magazine.

Slater, S. F., \& Olson, E. M. (2000). Strategy type and performance: the influence of sales force management. $\begin{array}{lllr}\text { Strategic Management } \quad \text { Journal, } & \text { 813-829. }\end{array}$ http://dx.doi.org/10.1002/1097-0266(200008)21:8<813::AID-SMJ122>3.0.CO;2-G 